\title{
Public Opinion Distribution and Party Competition in US Trade Policy
}

\author{
Gary Winslett \\ Political Science, Boston College, Cambridge, MA, USA
}

\section{INTRODUCTION}

$\mathfrak{E}$ XISTING scholarly literature generally either ignores or disparages the influence that mass public opinion has on contemporary US trade policy. Even when scholars have analysed public opinion's impact on US foreign policy, they have ignored trade policy (Nacos et al., 2000; Holsti, 2004). Because trade policy is rarely voters' highest priority, it is assumed that political actors face few electoral consequences for defying public opinion and thus have a relatively free hand to implement trade policy without regard for mass public opinion. As this paper demonstrates, even though trade is generally not voters' highest priority, political actors still face consequences for being on the wrong side of public opinion on trade. These consequences guide trade policy by channelling the political competition between the parties over that policy.

Within the literature on trade politics, early works depicted trade policy as driven by more concentrated interests rather than the general public (Schattschneider, 1935). This depiction continues to be the conventional wisdom. For example, Guisinger (2009) found that trade issues are generally low in salience and segued from that finding into the argument that this low salience means that the general public's preferences are a poor predictor of trade policy. Destler's (2005) account of US trade policy also generally ignores public opinion in favour of narrower interests and institutional dynamics. Shoch (2001) too passes over public opinion in favour of four other factors in explaining how party competition influences trade policy: the President's preference, the preferences and cohesion of the party caucuses, the willingness of Congress and the President to compromise, and whether control of the government is divided or unified. While there is considerable merit in these scholars' explanations of US trade policy formulation, those explanations can be supplemented if the distribution of public opinion and its guidance of political party competition are more fully taken into account.

My argument rests on a few assumptions. First, political actors want to remain in power. Second, political actors tend to value staying in power more than they value holding to a given policy position. Political actors who defy public opinion are celebrated as courageous and are rare, precisely because those who accept unpopularity and defeat rather than change their positions are the exception rather than the rule. Third, the primary ways an individual may lose power are to lose the backing of key supporters, to be viewed as out of step with public opinion, or to be seen as incompetent. Given these assumptions, with regard to trade policy, we should expect political actors to attempt to accomplish the following: (i) maintain the support of their party's leadership; (ii) maintain the support of their core constituents and (iii) be perceived as in agreement with the majority of the public. Given these incentives, we should expect to see political actors' behaviour be highly contingent on public opinion. The upshot of this is that political actors and their parties may be able to derive an electoral advantage from politically effective trade policies but that advantage is contingent upon the configuration of public opinion on trade policy. Thus, I contend that mass public opinion influences US trade policy by shaping how the two parties compete over trade. 
Mass public opinion configurations on trade can be classified into three basic categories based on whether public opinion is balanced or unbalanced, and if it is balanced, whether the division is primarily along partisan lines or not. If mass public opinion is unbalanced (i.e. if it is strongly more in favour of one policy direction than another), there is a strong incentive for each party to attempt to win over the large block of voters that sits at one end of the preference spectrum. If significantly more voters are strongly in favour of a policy than are neutral or opposed, the electoral logic is unambiguous. More votes can be gained by advocating the popular position. Furthermore, each party has a strong incentive to persuade the public that its policy position is not only good, but also that its position is better than the position advanced by the other party. There is much to be gained electorally if the other party can be cast as insufficiently in favour of that policy. These two facets, the unbalanced nature of public opinion and the incentive to differentiate one's own party from the opposition, mean that we should expect the two parties to enter into a bidding war in which each party tries to be the most in favour of that popular policy.

If public opinion is balanced (i.e. not as a whole more strongly in favour of one policy direction than another) and the fault line is partisan (the supporters of one party are in favour of a policy while the supporters of the other party are against it), then each party has an incentive to hold to its position and each individual has an incentive to remain loyal to their party. The parties cannot hope to gain more votes by switching positions than they would lose given that the other party already represents those voters who support their new position. Each individual has little incentive to defy their party's leadership if there is a reasonable expectation that the vast majority of their party colleagues will not break ranks. The benefit of breaking ranks will need to be extremely high to justify the cost of being seen as a party turncoat.

Because each side believes its position is best, it will want to gain credit for promoting that good policy. That credit becomes diluted, however, if a large proportion of the other party can claim that it too promoted the legislation. Therefore, for the majority party, it actually pays to craft the policy in a way that reduces the opposition's support for it. The opposition meanwhile believes that the policy is bad and thus will be unpopular. It therefore has an incentive to ensure that none of its members become tainted by supporting that policy. The opposition also gains by robbing the majority's proposal of the legitimacy that accrues from it being seen as bipartisan.

Each party's determination to present a unified front unifies the other party. The majority party, seeing its opposition united, has little hope of gaining support from them and so must rely on keeping its members in line. The opposition, seeing a unified majority that seems uninterested in offering real compromises, becomes that much more cohesive in its opposition. Regardless of which party starts the polarisation process, the partisan split in public opinion undermines concessions and creates an acrimonious spiral. Thus, in this scenario, we should expect policymaking to devolve into a Manichean conflict with the winner determined by which of the two parties most effectively creates unity in its party and division in its opponent.

Of the three potential public opinion configurations, a non-partisan split presents legislators and the President with the least onerous political constraints because it allows for a greater number of politically safe alternative strategies. This is a double-edged sword though. While it does mean that the politician has more potential strategies, it also means that they receive significantly less information about which strategy is politically safest. If public opinion is balanced and is non-partisan in its split, then many of the normal signals that indicate to a 
TABLE 1

Division and Distribution of Public Opinion and Party Competition in Trade Policy

\begin{tabular}{|c|c|c|}
\hline \multirow[t]{2}{*}{ Distribution } & \multicolumn{2}{|l|}{ Division } \\
\hline & Inter-party & Intra-party \\
\hline $\begin{array}{l}\text { Balanced } \\
\text { Unbalanced }\end{array}$ & $\begin{array}{l}\text { Manichean conflict } \\
\text { Bidding war }\end{array}$ & Local considerations prevail \\
\hline
\end{tabular}

political actor which is the safest policy to support do not operate. The balanced nature of public opinion means that the political actor does not receive an unambiguous signal about which policy direction is widely preferred. Meanwhile, the non-partisan nature of the split means that the individual does not have a clear idea of which direction their colleagues will go and dilutes the damage of voting against the wishes of the party's leadership, especially if the leadership itself is split. The only threat to that individual's political survival then comes from the constituency level. If the national level signals are ambiguous while the constituency level signals are clear, the individual legislator will likely follow their constituency's preferences (Table 1).

To examine the relationship between mass public opinion and US trade policy, I employ a comparative case study method. As George and Bennett (2005) have argued, case studies help complement statistical approaches because the two methods have different strengths. Case studies achieve a high level of conceptual validity, are ideal for exploring new hypotheses and assist the researcher in examining causal pathways (George and Bennett, 2005). These strengths mean that case studies can be particularly helpful in addressing the influence mass public opinion, through its channelling of party competition, has on trade policy.

Employing a case study method means that I am able to avoid engaging in conceptual stretching. Were I to employ statistical methods, many of the cases would be unclear in terms of which distribution they resembled and so would not be particularly helpful in examining what effect public opinion has on party competition in trade policy. The cases that I have chosen help explore this relationship precisely because they represent archetypes of the differing public opinion distributions. Public opinion was unbalanced on how to respond to Tiananmen Square in 1989-90, balanced and non-partisan on NAFTA ratification in 1992-93, and balanced and partisan on trade promotion authority in 2001-02.

\section{THE RACE TO SANCTION CHINA AFTER TIANANMEN SQUARE}

After the Tiananmen Square protests and subsequent repression, public opinion strongly favoured doing something to signal American indignation. Congressional Democrats and Republicans engaged in a bidding war over who could levy the heaviest sanctions on China and thus demonstrate that they were more thoroughly outraged and more supportive of Chinese protesters. Meanwhile, President Bush demonstrated little desire to engage in this bidding process but found his policy options constrained by the Congressional bidding war nonetheless.

As a non-market economy and a state that does not allow free emigration, China's most favoured nation status had to be renewed annually by Presidential waiver per the 
Jackson-Vanik amendment to the 1974 Trade Act; China first received this waiver in 1980 (Skidmore and Gates, 1997). From 1980 to 1989, China was granted most favoured nation status by presidential waiver un-controversially (Destler, 2005). The public's views on China were largely positive at this time; in February 1989, 72 per cent of respondents held very or mostly favourable opinions of China (Gallup, 1989). In April 1989, the Tiananmen Square protests began. By the middle of May, American media outlets were closely covering the protests. Americans were generally aware of the protests and subsequent massacre. Seventy-nine per cent reported following the events very or somewhat closely (ABC News/Washington Post 1989a).

The Tiananmen Square crackdown significantly altered Americans' views on China. In contrast to the positive views reported in February, in June only 16 per cent held favourable opinions of China, while 28 per cent held a somewhat unfavourable view, and 50 per cent held a very unfavourable view (Los Angeles Times 1989). With respect to what would constitute an appropriate policy, public opinion overwhelmingly favoured the American government doing something to signal disapproval of the Chinese government's human rights abuses. Sixty-seven per cent believed that the United States should issue a strong protest even if it set back US-China relations (Harris Survey, 1989). Seventy-five per cent favoured suspending arms sales and 60 per cent favoured restricting American investment in China (Gallup, 1989a, 1989b). Thirty-seven per cent even supported a complete ban on US trade with China (ABC News/Washington Post, 1989b). The outrage was similar among liberals and conservatives and particularly strong among the attentive public (Suettinger, 2003). American public opinion on this issue was clearly unbalanced.

Democrats were the first to push for greater sanctions but were quickly followed by Congressional Republicans; a reluctant President Bush was dragged along by the Congressional bidding war. In the massacre's immediate aftermath, Democratic congressmen such as Alan Cranston, Stephen Solarz, Sam Nunn and Claiborne Pell advocated a range of extensive sanctions (Hoffman and Dewar, 1989). Not to be outdone, Republicans such as Jesse Helms proposed revoking China's most favoured nation status and denying China access to technologically sophisticated American exports (Riddell, 1989).

Strategic considerations, a sense that he knew China better than Congress given his experience there in 1974-75, a concern for institutional prerogative and a preference for realist foreign policy motivated President Bush to pursue a much more moderate policy towards China than that preferred by the Congressional party delegations (Suettinger, 2003). Nevertheless, on 5 June, President Bush suspended arms sales to China although rejected broader trade sanctions (Weinraub, 1989). Without Congressional pressure, President Bush may not have even done that. His administration viewed the push for sanctions as a reckless temper tantrum. His trade representative Carla Hills argued that the arms sales suspension was necessary because 'clearly when you have death, violence, killing going on, it takes centre stage and quiet, sensible discussions on trade have to take second stage' while another Bush administration official stated that a major impetus behind the arms sale suspension was 'so we [the Bush Administration] wouldn't seem to be dragged along by the Hill' (Hoffman and Dewar, 1989). ${ }^{1}$ The President argued that engagement would yield greater reform than sanctions.

Democrats quickly deemed the suspension of arms sales insufficient and brought forth new efforts to display outrage at Beijing. John Glenn led a charge to block a US-China nuclear

\footnotetext{
1 Emphasis mine.
} 
energy deal (Walker, 1989). Tom Lantos, along with 51 co-sponsors, introduced a bill revoking China's most favoured nation status (House of Representatives (HR) 2613, 1989-1990). House Speaker Foley began publicly advocating expanded sanctions and criticised the President for being insufficiently strident in his condemnation of the Chinese government (Friedman, 1989a). In a meeting with a congressional committee, Secretary of State Baker mistakenly promised that the Bush Administration would suspend high-level intergovernmental meetings. The White House did not want to make this promise but once it had been made, the administration felt that it had to stick to it (Sutter 1998). Baker also promised that the administration would try to delay China's loan applications that were under review at the World Bank and IMF (Friedman, 1989b).

Democrats quickly outbid these measures. Senate Majority Leader Mitchell accused the President of being out of step with public opinion and of refusing 'to give outlet to the feelings of the American people' (Friedman, 1989c). Meanwhile, Democrats and Republicans in the House of Representatives engaged in a furious competition over who could add the most stringent anti-China amendment to the Foreign Aid Authorization Bill and thus claim the mantle of most ardent supporters of democracy. Proposed amendments included: ending all high-tech exports (Levine-D), prohibiting exports of controlled munitions (Gilman-R), prohibiting the issuance of new risk insurance policies for companies doing business in China (Weiss-D) and prohibiting export licences for satellites (Solomon-R) (Friedman, 1989c; HR 1487, 1989-1990). The House voted in favour of the bill containing these amendments by a whopping 418-0 (Tolchin, 1989). The Senate passed a similar version 81-10 (Suettinger, 2003). The bill barred the President from resuming arms sales or high-level meetings unless it was in the national security interest or China made progress on human rights (Tolchin, 1989).

During this process, President Bush worked to block legislation revoking China's most favoured nation status and to add carve-outs that would provide greater executive flexibility in implementing sanctions (Skidmore and Gates, 1997). He then used these exceptions to allow the sale of Boeing jets to the Chinese government (Sutter 1998). Simultaneously, he sent Brent Scowcroft and Thomas Eagleburger on a secret trip to Beijing to maintain USChina relations (Suettinger, 2003). These exceptions notwithstanding, the sanctions constrained US-China relations in ways that President Bush would not have pursued on his own.

The propensity of congressmen to not just support, but also claim credit for being the most in defence of Chinese dissidents was exemplified by the fact that over half of the House of Representatives, including high-profile members from both parties, chose not just to support but to co-sponsor a bill that would allow Chinese students in America to remain in the United States past their visas (HR 2712, 101st Congress, 1989; Suettinger, 2003). Once the bill became known as the Pelosi bill after its original sponsor, Republicans made sure that they would receive partial credit for the bill stating that on this issue, there were 'an awful lot of conservatives who feel as strongly as Nancy Pelosi' (Skidmore and Gates, 1997, p. 526). The measure passed the House and the Senate unanimously (Suettinger, 2003).

Seemingly, everyone supported the bill except President Bush. He opposed it because it denied what he saw as the executive's rightful primacy in foreign policy and because he thought it would damage the US-China relationship by humiliating the Chinese government (Skidmore and Gates, 1997; Suettinger, 2003). He therefore vetoed the bill and shortly thereafter announced that he would use an executive order to extend the same protections to Chinese students in America (Executive Order 12711, 1990). It was not his preferred policy but was inevitable and having it be an executive order at least allowed him to preserve his institutional prerogative and blunt the criticism that he was advancing a callous foreign policy. 
This case suggests several lessons. First, while Congressional Republicans and Democrats were eager to engage in a bidding war over who could be the most anti-Beijing, President Bush was not willing to participate in this. He was less sensitive to public opinion than Congress. He needed to actually manage US foreign policy and thus wanted to maintain good relations with China for geopolitical reasons regardless of China's human rights record. $\mathrm{He}$ believed in a realist foreign policy that placed a premium on promoting America's strategic interests over normative concerns and thought sanctions would accomplish little and may even be counterproductive (Dueck, 2010). He was not facing re-election for three years and could assume that the issue's salience would ebb by then. In any case, the Soviet Union was collapsing; foreign policy did not appear to be hurting his approval rating. Bush's approach shows that party competition logic will not override all other considerations for all political actors at all times.

On the other hand, Congress's bidding war consistently constrained the President. Without it, the suspension of arms sales to China (which is still in place today) may never have happened at all. Another lasting impact was that human rights became a consistent sticking point in opening trade with China. Permanent normal trade relations with China were granted only after human rights monitoring provisions were established (Destler, 2005). It was at a Congressional hearing that policy mis-coordination led James Baker to promise an end to highlevel intergovernmental meetings. This promise, and the perception of duplicity that breaking it created, generated a firestorm of criticism in December 1989 when it was revealed that Scowcroft and Eagleburger had been sent on their visit less than a month after the crackdown.

The bidding war also meant that President Bush was forced to establish benchmarks for policy success that he did not want. President Bush understood that attempting to sell the American people a realist foreign policy was a political non-starter because it would be rejected as callous and amoral. He had to argue that his approach was a better means of promoting democracy in China (Skidmore and Gates, 1997). Later, when the Chinese government had made no progress on this front, Bush's China policy was deemed a failure. But it was only deemed as such because it was judged on goals that it was not actually designed to achieve. This criterion only came about because of the Congressional bidding war. President Bush may not have been a willing participant in the bidding war, but it still dragged him in its direction. That it could change the policies pursued by an institutionally independent, reluctant, powerful, popular political actor demonstrates just how strong the outbidding vortex can be.

One potential alternative explanation is that Congress already wanted to curtail trade with China and Tiananmen Square simply gave them the excuse. That argument is unsatisfactory. As Destler (2005) points out, in 1989, trade was not high on the legislative agenda, the US trade deficit was shrinking, and Speaker Jim Wright was replaced by Tom Foley who was a much stronger free trade advocate.

Another alternative explanation is that the US response was not a product of public opinion and that even if public opinion had been different, the US response would have been the same. But this too is unconvincing. Let us suppose that conservatives agreed with President Bush's inclination that as unfortunate as the Tiananmen Square massacre was, punishing China would be bad policy. This would have meant that the underlying public opinion was a balanced partisan split. Under that condition, we should expect a Manichean deadlock. There was actually an event on this issue over which opinion was divided along party lines and that division did produce just such a deadlock. After the President vetoed the Pelosi Bill but 
replaced it with an executive order, Democrats fiercely criticised the President and pushed for a veto override (Xie, 2008). The vehemence of Democratic criticism despite the fact that student protection had been implemented anyway convinced Republicans that the veto override proposal was what Minority Whip Simpson called a 'trash-the President' move by Democrats; Republicans stood opposed to the motion and so it did not pass (Dewar, 1990). Had the larger debate on sanctions resembled this kind of balanced partisan split, it is likely that President Bush would have found it easier to do what he preferred, condemn the crackdown rhetorically but do nothing that would undermine the US-China relationship.

Finally, what if it the public opinion distribution had been a balanced non-partisan split? There is not an event on this particular issue that fits that description but the debate over NAFTA a few years later did have this kind of underlying public opinion and thus may offer some clues as to how that kind of distribution may have affected the US response to Tiananmen Square.

\section{LOCAL PREFERENCES AND INTERNATIONAL TRADE - THE DEBATE OVER NAFTA RATIFICATION}

With regard to ratifying NAFTA, President Clinton, House Republicans and House Democrats all received ambiguous signals from public opinion and from their own parties. Each of them faced little fear of being on the wrong side of public opinion or of being perceived as a party turncoat. That meant that the greatest threat to their continuation in government emanated from the possibility that they would lose the support of constituencies that had supported them in the previous election. Thus, the President and individual legislators attempting to defend the interests of those constituencies defined the political competition surrounding NAFTA ratification.

In 1992, with the economy stagnating and NAFTA negotiations accelerating, the issue became part of the presidential election campaign. ${ }^{2}$ NAFTA underscored and crystalised the increasing extent of international trade in the public mind. As Thomas Donahue of the AFLCIO put it, 'GATT is something nobody understands and NAFTA is something everybody understands' (Aaronson, 2001, p. 139). Clinton was thus faced with a high-profile issue that he had to respond to but received no clear signals from broader public opinion or his party as to which position was the most prudent.

Public opinion was split and non-partisan on the issue. In a poll taken in September 1992, 27 per cent favoured NAFTA, 34 per cent were opposed, and 40 per cent were either undecided or had not heard enough about it (NBC News/Wall Street Journal, 1992a). Other polls showed similar results (Gallup/Newsweek, 1992; NBC News/Wall Street Journal, 1992b). Thus, general public opinion did not demonstrate which policy position would reap greater electoral benefits. Furthermore, even within the Democratic Party, opinion was split. When asked whether their party should support or oppose NAFTA, 40 per cent of Democrats favoured supporting it while 41 per cent opposed it (ABC News/Washington Post, 1992). Generally, Democrats who were college-educated, white-collar and/or suburban were more likely to favour NAFTA, whereas Democrats who were not college-educated, blue-collar and/ or urban were more likely to oppose NAFTA (Shoch, 2001).

\footnotetext{
${ }^{2}$ By September, over 50 per cent of Americans had read or heard about NAFTA (Gallup, 1992) and 40 per cent were following the issue very or somewhat closely (News Interest 1992).
} 
Candidate Clinton's strategy was to give something to both sides and so he endorsed NAFTA while also criticising it as inadequate on environmental protection, labour standards and import spikes, and demanded side agreements on these issues. In the short term, this helped Clinton satisfy both wings of his party but it left a lingering confusion as to whether he actually favoured the agreement. ${ }^{3}$

That lingering confusion was fed by the opaqueness of Clinton's NAFTA stance during the first months of his presidency. His trade representative, Mickey Kantor, was not identified with either trade liberalisation or protectionism (Destler, 2005). Clinton was determined to satisfy both constituencies that elected him (college-educated, white-collar Democrats and non-college, blue-collar Democrats). A resolution that satisfied both groups promised to make ratification easier. Indeed, of those who said they opposed NAFTA, 40 per cent said they would favour it if they deemed the side agreements adequate (Time/CNN/Yankelovich Partners, 1993). Attempting to thread the needle on the side agreements was understandable in theory but led to the Clinton Administration taking no real position at all in practice. Nuance devolved into confusion. Kantor and Secretary of Labor Reich argued for a hardline approach on the side agreements, whereas Treasury, State Department and National Economic Council officials pushed for weaker side agreements (Shoch, 2001).

The problem was that Clinton allowed this internal dispute to take place in public, creating an impression of division, sloppiness and confusion within the Administration (Destler, 2005). Compounding this, Clinton's propensity for revisiting previously decided issues meant that his staff frequently treated policy matters as still negotiable even after he had made a decision (Destler, 2005). Clinton's lack of clarity to this point was exemplified by the fact that 52 per cent of Americans still did not know what position he held on NAFTA and another 19 per cent believed he had no position at all (CBS News/New York Times, 1993).

To make matters worse, the Clinton Administration seemed incapable of sticking to a position if that position garnered opposition. In May, the White House rescinded its relatively weak initial offer and called for including trade sanctions as an enforcement mechanism after some Democrats expressed a desire for tougher provisions (McParland 1993). Significantly, this more stringent position was still not enough to satisfy labour organisations (Shoch, 2001). ${ }^{4}$ When Republicans began withdrawing their support, Clinton again shifted to a more flexible position (Sands, 1993). If a tough negotiating position was going to lose Clinton Republican support but still not acquire labour's support, then a weaker position that at least would gain the support of one of those groups was the strategically superior choice. ${ }^{5}$ Thus, Clinton announced his unambiguous support for NAFTA and its weakened side agreements.

The public opinion and party signals that Republicans received were also mixed. Twenty per cent of respondents said that their Congressman supporting NAFTA would make them less likely to vote for them while 20 per cent said that it would make them more likely but 53 per cent said that it would make no difference (ABC News, 1993). ${ }^{6}$ The vast majority of

\footnotetext{
${ }^{3}$ NAFTA was signed in December 1992, after the election but before Clinton took office. It had to be ratified by the end of 1993 . Given that the Senate overrepresented export-oriented agricultural states, NAFTA's most difficult hurdle would be in the House of Representatives (Shoch, 2000).

${ }^{4}$ Many but not all environmental groups were pleased with the new tougher policies and so endorsed NAFTA (Audley, 1997; Destler, 2005).

5 This approach had the added bonus of burnishing his reputation as a centrist New Democrat, a reputation that had been bruised during the fight over the federal budget earlier in the year.

${ }^{6}$ A second poll asking that question had 60 per cent say no effect (Gallup/CNN/USA Today, 1993).
} 
Americans did not know what their representative's position was (CBS News/New York Times, 1993). Also, while most Republicans supported free trade, there were enough Republican voices such as Pat Buchanan advocating economic nationalism that a Republican Congressman could oppose NAFTA without being branded a party turncoat (Mayer, 1998).

Not only did Republicans receive no clear signal from the public or from within the party during the spring and summer of 1993 they also received no consistent signals from the White House. Had there been an unbalanced or partisan split public opinion distribution, Republicans would have known which course was the safest for them. Without these signals, the President's intentions became a crucial piece of information. Republicans were unwilling to push for ratification without help from the President. Without clear signals from constituents or the President, most congressmen had no choice but to wait for more information about which policy position was in their best interest. Thus, only 72 congressmen declared a position on NAFTA in 1992 or the first eight months of 1993, whereas 159 declared in September, 55 did so in October, and 149 decided in November (Box-Steffensmeier et al., 1997).

Clinton's decision to fully support ratification finally gave them the signal they needed. Although this signal was not mixed in itself, it had ambivalent implications. On the one hand, many Republicans were reluctant to sign on to an agreement that could be construed as a victory for Clinton (Merida and Cooper, 1993). On the other hand, Republicans had largely supported NAFTA while George H.W. Bush was President and so this presented them with an opportunity to achieve their preferred policy. Republicans also liked that NAFTA was driving a wedge into the Democratic coalition (Destler, 2005).

Still, the ambiguous public opinion and party signals meant legislators were often best served by supporting constituencies that helped them get elected in the first place. It was for this reason that Republican support for NAFTA broke down along regional lines. Representatives from high-tech, white-collar districts or export-oriented agricultural districts, especially in the South and the West, and who received more campaign contributions from business supported NAFTA, whereas Republicans who opposed NAFTA predominantly hailed from bluecollar industrial districts, especially in the Midwest and Northeast (Shoch, 2001).

In addition to the same ambiguous public opinion signals faced by the President and House Republicans, House Democrats also had a split party leadership. While President Clinton supported NAFTA, House Majority Leader Gephardt and Majority Whip Bonior were NAFTA's principal opponents (Lee, 1993). Given this set of circumstances, House Democrats' support for NAFTA also broke along regional and constituency lines. Similar to the Republicans, Democrats who represented white-collar or export-oriented agricultural districts, especially in the South and West, were more likely to support the agreement, whereas those who represented blue-collar, urban or industrial districts, especially in the Midwest and Northeast, or who received major campaign contributions from labour were more likely to oppose NAFTA (Shoch, 2001).

These disparate regional interests allowed President Clinton to make side deals to win support for NAFTA. One important side deal was the implementation of a triple transformation test, which amounted to greater protection for textiles. This was a major factor in gaining the support of congressmen from textile-producing states (Destler, 2005). Another was the creation of a North American Development Bank which won the support of the Congressman who came up with idea and solidified the support of Hispanic and environmental organisations (Mayer, 1998). A third involved increasing protection for citrus and sugar farmers to win the support of representatives from Florida (Garrett, 1993). President Clinton promised to protect the interests of tomato and peanut growers as well (Avery, 1998). These side deals helped 
secure NAFTA ratification in the House of Representatives by a margin of 234-200 (HR 3450. 103rd Congress). One hundred and thirty-two Republicans and 102 Democrats supported it while 43 Republicans and 156 Democrats opposed it (Shoch, 2001).

The primary alternative hypothesis to this argument is that regional and sectoral interests led to the weakness of party alignment rather than the other way around. This argument has been advanced by Thorbecke (1997). His quantitative analysis shows that the presence of these differing interests was correlated with congressmen's votes on NAFTA (Thorbecke, 1997). This argument, however, gets the causal mechanism backwards. Rather than causing party weakness, the correlation of representatives' votes with these interests was facilitated by the fact that public opinion on NAFTA was divided evenly and in a non-partisan way. If Thorbecke's argument were correct, then we should have seen a weak party effect in other trade policies where these differing interests were present such as the 1988 Trade Bill or President George W. Bush's pursuit of trade promotion authority in his first term. Instead, the party effect in the voting behaviour on those pieces of trade legislation was strong despite differing regional interests (Shoch, 2001).

This case suggests several lessons. First, a non-partisan split in public opinion reduces the bargaining power of individual interests within a party. Had Republicans been uniformly opposed to NAFTA, the bargaining position of organised labour would have been much stronger. President Clinton would have been forced to either give labour whatever concessions it wanted or accept the defeat of NAFTA. Instead, the existence of potential Republican support meant that President Clinton, upon determining that acquiring labour's support was all but impossible, had another source of potential support. Furthermore, once labour support could not be had, Clinton benefited from criticising labour because that reduced Republicans' concern that NAFTA ratification would be perceived as an unalloyed victory for the Democrats.

Second, under a non-partisan balanced split, special interests increase their bargaining power by remaining uncommitted. President Clinton could spurn labour without facing any real electoral threat. Given the antipathy between labour and the Republicans, labour threatening to support Republicans would not have been credible. Labour may still have been able to maintain a strong bargaining position if it had left open the possibility of supporting the President's push to ratify NAFTA. Intransigence to even the toughest proposals made by the Clinton Administration squandered that. Once it became clear that there was no chance of securing labour's support, labour was marginalised. Moderate environmentalist groups provide a good counter-example. By making it clear that their support could be won at a high but not impossibly high policy cost, moderate environmentalist groups were able to increase the extent to which the side agreements reflected their preferences (Audley, 1997; Avery, 1998; Mayer, 1998). The lesson for special interests is that being intransigent without being the difference between success and failure is a recipe for being excluded from the policymaking process altogether.

\section{THE VERY PARTISAN BIPARTISAN TRADE PROMOTION AUTHORITY OF 2001}

In 2001, President Bush asked for fast-track authority to pursue another round of WTO negotiations, a Free Trade Area of the Americas agreement, and bilateral trade deals with Singapore and Chile. The public opinion distribution on the appropriateness of granting such authority was balanced but partisan. Fourteen per cent of Americans strongly favoured granting it, 32 per cent favoured it, 32 per cent were opposed, and 14 per cent were strongly opposed (Pew Research Center for the People, 2001). While Republicans were in favour by a 
margin of 63-32 per cent $(+31)$, Democrats were opposed by a margin of 56-39 per cent $(-17)$, meaning that there was a 48-point spread between the two parties' positions (Pew Research Center, 2001).

There was also a partisan split on the major sticking point in the negotiation (the extent to which fast-track authority should include labour and environmental provisions). Republicans were twice as likely to say that encouraging economic growth was more important than protecting the environment, while Democrats were more likely to say the opposite (ABC News/ Washington Post, 2001). ${ }^{7}$ Republicans were also twice as likely as Democrats to have very little or no confidence in organised labour (Gallup/CNN/USA Today, 2001).

Given this public opinion distribution, it would make sense for Republicans to try to pass trade promotion authority without labour and environment provisions if they could. However, given that over 50 Republicans had voted against every trade liberalisation bill since NAFTA, the Bush Administration would need some Democratic help (Destler, 2005). A compromise seemed necessary, but the two parties saw themselves as so far apart that no proposal seemed to satisfy both parties. Senator Grassley said that the difficulty with 'Democrats' solutions on labor and environmental issues [was] that for every Democratic vote it picks up, you lose one Republican vote' (Allen and Goldstein, 2001).

On 13 June 2001, House Republicans introduced HR 2149, which would grant President Bush fast-track authority but did not include any environmental or labour provisions whatsoever (HR 2149. 107th Congress). House Democrats reacted angrily. Richard Gephardt encapsulated Democrat's feeling, calling the bill Republicans' 'my way or the highway' solution (Sek, 2003, p. 5). Bill Thomas, the Republican who chaired the Ways and Means Committee, made it clear that he hoped to make the minimum amount of concessions necessary to acquire whatever few Democrats' support would be required to pass the bill (Destler, 2005). As part of this strategy, Thomas sidestepped the senior Democrats on the Ways and Means Committee (Rangel, Matsui, and Levin) and instead worked with three more junior Democrats known to be free trade advocates (Destler, 2005). When Democrat Carl Levin approached Thomas to try to broker a compromise, Thomas rejected his overture saying, 'I consider you part of the enemy on this issue' (Destler, 2005, p. 292). To make matters worse, the Bush Administration used 9/11 to connect national security and trade, implying that Democratic opposition to trade promotion authority on Republican terms was tantamount to a lack of patriotism (Kahn, 2001a). This of course outraged Democrats, making them even less willing to compromise, although it did rally support from some of the Republicans who had opposed trade liberalisation earlier.

In late September, Thomas released a summary of a compromise plan; the Democrats deemed the measures insufficient but made a counter-offer (Washington Post, 2001). The Republicans ignored this counter-offer and introduced HR 3005 modelled on Thomas's plan. Democrats res"ponded with their own bill, HR 3019. After rancorous negotiation sessions brought the two sides no closer together, the Republican bill was approved and the Democratic bill rejected along party line votes (Destler, 2005). In November, Charlie Rangel sent the Republican leadership a document outlining what would be needed for the trade promotion act to gain Democratic support; as Destler points out, three of the four issues should have presented little problem to the Republicans, but the fourth entailed a possible future toughening of labour regulations in the United States which Republicans considered

\footnotetext{
${ }^{7}$ Republicans: $64-32$ split. Democrats: $37-59$ split.
} 
anathema (Destler, 2005). The Republican leadership chose to not give Rangel the dignity of a response (Destler, 2005). Democrats became so angry at the naked way in which they had been marginalised that even those who normally supported trade liberalisation withdrew their support (Kahn, 2001b). Democrats also believed that a new free trade deal would be unpopular and so they might be able to use that to their advantage in the 2002 mid-term elections (Shoch, 2001). Given the 9/11 attacks, if they were going to criticise President Bush, it had to be on economic issues.

For their part, some Congressional Republican leaders such as Tom DeLay were not just willing but eager to make the vote as partisan as possible because they believed it would be popular with big business and hoped to win greater support from corporate donors (Destler, 2005). A combination of arm-twisting, procedural manipulation and concessions brought recalcitrant Republicans on board. Efforts to win every last Republican vote were so relentless and so successful that nearly a dozen hard-core protectionists who had even voted to remove the United States from the WTO the previous year were convinced to vote for the trade promotion authority legislation (Destler, 2005). The final vote on the not-soappropriately titled Bipartisan Trade Promotion Authority Act of 2001 was 215 in favour and 214 against; it was the most partisan vote on a trade bill in seven decades (Destler, 2005).

Once the bill moved to the Senate, action on it became somewhat less rancorous. The Senate is more supportive of trade liberalisation than the House due to its composition and so there was less worry that the bill could not get adequate support. Even so, the partisan politics of the House bill meant that Senate Democrats were unwilling to get nothing in exchange for their support. Their colleagues in the House might have been powerless to extract concessions but the threat of the filibuster meant that Republicans had no hope of passing the bill entirely on their own. In exchange for their support, Senate Democrats wanted the legislation to include trade adjustment assistance, which would provide healthcare to workers who had lost their jobs as a result of trade. Senate Republicans disliked this provision and some even argued that passing no trade promotion authority was preferable to including healthcare provision (Destler, 2005). Most Republicans in the Senate as well as the Bush Administration disagreed, accepting healthcare benefits as the price of trade promotion. The bill passed the Senate, $66-30 .^{8}$

This case demonstrates a few points. First, a partisan split distribution may decrease the power of the opposition party to constrain the majority party in institutions such as the House of Representatives where a simple majority is usually all that is required to advance legislation, but it still constrains the majority party in other ways. It makes the margin for error exceedingly tight which increases the bargaining power of members in the majority party who are willing to play the spoiler. Protectionist concessions on steel and textiles as well as greater subsidies for agriculture were needed to win the support of some Republicans (Destler, 2005). It also delayed fast-track authority. President Bush wanted it no later than November 2001 to strengthen his bargaining position at the opening of the Doha Round trade negotiations (Allen and Goldstein, 2001). He did not receive it until the following August, nearly a full year later.

\footnotetext{
${ }^{8}$ Final passage of a conference bill was delayed further by what can only be described as a childish partisan squabble over such petty matters as whose turn it was to chair a conference; Destler (2005, p. 297) refers to this episode as 'a bizarre endgame that served as a poster child for interparty and interchamber distrust'.
} 
Second, each party was at its most intransigent when it perceived itself as not needing the other. Republicans felt that given their House majority, there was no need to compromise with Democrats in that chamber. Democrats for their part assumed that Republicans would not be able to find enough votes and would have to come back to the bargaining table with a better offer.

Third, this case shows how necessary it is that some portion of the opposition be willing to compromise. Even with a House majority, control of the Presidency, a Senate broadly in favour of trade liberalisation, and an almost totally unified party, approval of trade promotion authority would not have been possible without some Democratic support in both the House and the Senate. The institutional design of Congress means that in the vast majority of cases, for significant legislation to be enacted, some part of the minority has to be willing to exchange its support for being allowed to make small changes to the legislation. This suggests then that the relative division within the two parties often determines the odds of enacting major legislation; gridlock is most likely when the opposition is more unified than the majority.

\section{DISCUSSION}

The argument advanced in this paper generalises well to other events in US trade policymaking. In September 1985, the Reagan administration moved its trade policies in a more protectionist direction by bringing forward Section 301 cases against Japan (Shoch, 2001). Why would a Republican Administration committed to trade liberalisation do that? They did that because the Democrats were gaining an electoral advantage on trade by presenting themselves as the party that would 'get tough' on allegedly unfair imports and the administration wanted to make sure that they did not get outbid on the issue (Shoch, 2001). Why did Democrats believe that trying to outbid Republicans was a political winner? Because by a more than 2 to 1 margin Americans believed that imports from Japan did more harm than good to the economy and favoured import taxes on Japanese products (Harris Survey, 1985; Roper Report 85-5,1985). Unbalanced public opinion launched the bidding war that forced a freetrading Administration to move in a protectionist direction. Two decades later, a similar public opinion distribution prompted Congress to kill a deal that would have transferred control of six US ports to a company from Dubai. ${ }^{9}$

The 217-215 House vote that ratified the Central American Free Trade Agreement in July 2005 was as partisan as the 2001 House vote to grant President Bush trade promotion authority for many of the same reasons (Sparshott, 2005). The 237-197 vote on admitting China to the WTO in 2000 by granting them permanent normal trade relations came with the same kind of constituency catering that characterised the ratification of NAFTA (McGregor, 2000). Legislators' freedom to vote against party lines was made easier by the fact that approval of admitting China to the WTO was split with 43 per cent of Americans in favour and 45 per cent opposed; the approval margins among Republicans and Democrats were almost identical (Gallup/CNN/USA Today, 2000).

\footnotetext{
${ }^{9}$ Even when they were told that Dubai Ports World managed other ports and that those ports' security was managed by the Coast Guard, 82 per cent of Americans were opposed to the deal compared to only 15 per cent who approved. This preference held across party identification, age, income and education level (ABC News/Washington Post, 2006).
} 
The cases selected for this analysis were chosen because they represented archetypes of the differing public opinion distributions. Most cases, however, will not be such neat archetypes. Still, the cases presented here point to what we should expect in mixed cases. In cases where there is some degree of partisan split and some degree of non-partisan split, we should expect components of the defining features that accompany these two types of underlying opinion distribution, Manichean conflict and catering to core constituencies. And indeed, we do see a great deal of both of those dynamics in many issues in American trade policy precisely because public opinion on most trade issues contains some amount partisan and non-partisan division. Likewise, in cases where public opinion is unbalanced but where there is some non-partisan split, then we should see the parties cater to those constituencies that provide opportunities to outbid their opposition.

One of the alternative hypotheses to the argument that public opinion drives the parties' approaches to trade is that trade policies are driven by ideas (Goldstein, 1993; Nollen and Quinn, 1994). The analysis presented in this paper suggests some strengths and limitations of that assertion. On the one hand, George H.W. Bush's realist bent, Republicans' preference for free trade and Democrats' commitment to labour had efficacy. On the other hand, public opinion driven party competition tempered Bush's realism, increased the impact of Republican's free trade proclivities during the NAFTA debate by bringing more Democrats on board and stiffened Democrats' desire for labour standards and Republican opposition to such standards being included in trade legislation by adding an electoral incentive to the ideological incentive already present. This paper suggests a consideration whose incorporation can augment these ideational theories.

Examining public opinion may also augment our understanding of veto players in trade policy formulation. A greater number of veto players does inhibit trade liberalisation, and it is often assumed that divided governments increase the number of veto players by increasing the necessity of placating both parties (Mansfield et al., 2008). That may be the case in some situations but as this paper has shown, if the underlying public opinion is split in a non-partisan way, divided government may promote trade liberalisation by creating incentives for members of both parties to support it.

Likewise, examining public opinion also speaks to the debate about government division and trade negotiation. Some scholars assert that divided government creates greater opportunities for trade liberalisation (Sherman, 2002). Others argue that divided government impedes trade liberalisation (Lohmann and O'Halloran, 1994; Milner and Rosendorff, 1997). The cases presented here show some of the conditions under which each of these may be correct. Divided government may act as an impediment to liberalisation under partisan balanced public opinion; one party supports the liberalisation but is blocked by the opposite party. Conversely, divided government may promote trade liberalisation under a non-partisan split by giving some members of each party their own reasons for supporting the legislation.

This paper also demonstrates that the importance of presidential leadership is not just relevant in terms of the president being the country's chief international negotiator but also in the fact that he is the central figure in parties' political competition. Presidents are not just chief executives; they are also leaders of their parties. They are the chief targets that the opposition hopes to weaken. Their popularity is the main asset their party must maintain to stay competitive in the next election. This fact is not lost on legislators. The bidding process over who could punish China the most stopped as soon as Republicans perceived that process to be harming their president. During NAFTA, Republicans became less reluctant to support the bill once it became clear that NAFTA was not going to be perceived as belonging solely to President 
Clinton, especially since it was alienating one of the Democrats' major constituencies, organised labour. President Bush's unwillingness to rein in House Republicans eager to marginalise Democrats contributed to the polarisation in the debate over trade promotion authority.

Finally, this paper also contributes to our understanding of congressional involvement in foreign policymaking. Rhode (1994) contends that congressional activism is a function of partisanship, that greater partisanship beginning in the 1970s created greater congressional assertiveness. This paper suggests one reason that may be so. Partisanship is one of the potential public opinion signals that give congressmen a clear understanding of what is in their interests. Of the three cases examined here, Congress became very active during the first case because it was clear what outcome would most help their party (convincing voters that they were the more ardently supportive legislators of Chinese protesters). During the third case, partisanship also signalled to legislators what side they should be on and helped solidify party support among legislators who considered voting with the other party. It was during the second case (NAFTA), especially early on, where Congress was the least active precisely because the non-partisan nature of the public opinion split meant that congressmen did not have adequate information about what was in their best interest until the parties' leadership began lobbying in favour of the bill and side deals that increased the benefit of supporting NAFTA were negotiated.

In summation, this paper has attempted to demonstrate that, contra to the conventional wisdom, public opinion matters in US trade formulation by influencing how the two major parties compete with each other over a given trade issue. Unbalanced public opinion leads to a bidding war between the parties, balanced partisan splits in public opinion lead to Manichean conflict, and balanced non-partisan splits encourage constituency catering.

\section{REFERENCES}

Aaronson, S. (2001), Taking Trade to the Streets: The Lost History of Public Efforts to Shape Globalization (Ann Arbor, MI: University of Michigan Press).

ABC News (1993), ABC News Poll, November (Storrs, CT: The Roper Center for Public Opinion Research, University of Connecticut).

ABC News/Washington Post (1989a), ABC News/Washington Post Poll, June 1989a. Retrieved from the iPOLL Databank (Storrs, CT: The Roper Center for Public Opinion Research, University of Connecticut).

ABC News/Washington Post (1989b), ABC News/Washington Post Poll, June (Storrs, CT: The Roper Center for Public Opinion Research, University of Connecticut).

ABC News/Washington Post (1992), ABC News/Washington Post Poll, July (Storrs, CT: The Roper Center for Public Opinion Research, University of Connecticut).

ABC News/Washington Post (2001), ABC News/Washington Post Poll, July (Storrs, CT: The Roper Center for Public Opinion Research, University of Connecticut).

Allen, M. and A. Goldstein (2001), 'Bush Sets a Deadline on Trade Pact Powers', The Washington Post, 28 July.

Audley, J. (1997), Green Politics and Global Trade: NAFTA and the Future of Environmental Politics (Washington: Georgetown University Press).

Avery, W. (1998), 'Domestic Interests in NAFTA Bargaining', Political Science Quarterly, 113, 2, 281 305.

Box-Steffensmeier, J., L. Arnold and C. Zorn (1997), 'The Strategic Timing of Position Taking in Congress: A Study of the North American Free Trade Agreement', American Political Science Review, 91, 2, 324-38.

CBS News/New York Times (1993), CBS News/New York Times Poll, November (Storrs, CT: The Roper Center for Public Opinion Research, University of Connecticut).

Destler, I. M. (2005), American Trade Politics, 4th edn (Washington: Petersen Institute for International Economics). 
Dewar, H. (1990), 'Senate Narrowly Votes to Sustain Veto of Chinese Students Bill', The Washington Post, 26 January.

Dueck, C. (2010), Hard Line: The Republican Party and US Foreign Policy Since World War II (Princeton, NJ: Princeton University Press).

Executive Order 12711 (1990), Policy Implementation with Respect to Nationals of the People's Republic of China, 11 April 11 (Washington, DC: US Department of State).

Friedman, T. (1989a), 'Crackdown in China; Foley Says the US Should Consider Further Sanctions Against China', The New York Times, 19 June.

Friedman, T. (1989b), 'US Suspends High-level Links to China as Crackdown Goes On', The New York Times, 21 June.

Friedman, T. (1989c), 'Congress, Angry at China, Moves to Impose Sanctions', The New York Times, 23 June.

Gallup (1989a), Gallup Poll, February (Storrs, CT: The Roper Center for Public Opinion Research, University of Connecticut).

Gallup (1989b), Gallup Poll, June (Storrs, CT: The Roper Center for Public Opinion Research, University of Connecticut).

Gallup (1989c), Gallup Poll, September (Storrs, CT: The Roper Center for Public Opinion Research, University of Connecticut).

Gallup/CNN/USA Today (1993), Gallup/CNN/USA Today Poll, November (Storrs, CT: The Roper Center for Public Opinion Research, University of Connecticut).

Gallup/CNN/USA Today (2000), Gallup/CNN/USA Today Poll, April (Storrs, CT: The Roper Center for Public Opinion Research, University of Connecticut).

Gallup/CNN/USA Today (2001), Gallup/CNN/USA Today Poll, June (Storrs, CT: The Roper Center for Public Opinion Research, University of Connecticut).

Gallup/Newsweek (1992), Gallup/Newsweek Poll, October (Storrs, CT: The Roper Center for Public Opinion Research, University of Connecticut).

Garrett, M. (1993), 'Clinton Nears Victory Margin for Trade Pact; Florida Lawmakers Sign On', The Washington Times, 16 November.

George, A. and A. Bennett (2005), Case Studies and Theory Development in the Social Sciences (Cambridge, MA; MIT Press).

Goldstein, J. (1993), Ideas, Interests, and American Trade Policy (Ithaca, NY: Cornell University Press).

Guisinger, A. (2009), 'Determining Trade Policy: Do Voters Hold Politicians Accountable?', International Organization, 63, 3, 533-57.

Harris Poll (1985), Harris Survey Poll, September (Storrs, CT: The Roper Center for Public Opinion Research, University of Connecticut).

Harris Poll (1989), Harris Poll, June (Storrs, CT: The Roper Center for Public Opinion Research, University of Connecticut).

Hoffman, D. and H. Dewar (1989), 'Bush Suspends Military Sales to China; President Rejects Calls From Congress for More Severe Action', The Washington Post, 6 June.

Holsti, O. (2004), Public Opinion and American Foreign Policy, Revised Edition (Ann Arbor, MI: University of Michigan Press).

House of Representatives (HR) 1487, 101st Congress (1989-1990), Foreign Relations Authorization Act, Fiscal Years 1990 and 1991 (Washington, DC: US Congress).

House of Representatives (HR) 2149, 107th Congress (2000-2001), Trade Promotion Authority Act of 2001 (Washington, DC: US Congress).

House of Representatives (HR) 2613, 10Ist Congress (1989-1990), To Suspend Most-Favored-Nation Treatment for the Products of the People's Republic of China and to Suspend Further Operations by the Overseas Private Investment Corporation (OPIC) in the People's Republic of China Until That Country Recognizes and Protects Fundamental Human Rights (Washington, DC: US Congress).

House of Representatives (HR) 2712, 101st Congress (1989-1990), Emergency Chinese Immigration Relief Act of 1989 (Washington, DC: US Congress).

House of Representatives (HR) 3005, 107th Congress (2000-2001), Bipartisan Trade Promotion Authority Act of 2002 (Washington, DC: US Congress).

HR 3019. 107th Congress (2000-2001), Comprehensive Trade Promotion Act.

House of Representatives (HR) 3450, 103rd Congress (1993-1994), North American Free Trade Agreement Implementation Act (Washington, DC: US Congress). 
Kahn, J. ( 2001a), 'Gain for Trade Bill That Some See as Aid in Terrorism Fight', The New York Times, 4 October.

Kahn, J. (2001b), 'House Supports Trade Authority Sought by Bush', The New York Times, 7 December.

Lee, J. (1993), 'NAFTA Running Into Unions' Brick Wall', The USA Today, 4 October.

Lohmann, S. and S. O'Halloran (1994), 'Divided Government and US Trade Policy: Theory and Evidence', International Organization, 48, 4, 595-632.

Los Angeles Times (1989), Los Angeles Times Poll, June (Storrs, CT: The Roper Center for Public Opinion Research, University of Connecticut).

Mansfield, E., H. Milner and J. Pevehouse (2008), 'Democracy, Veto Players, and the Depth of Regional Integration', The World Economy, 31, 1, 67-96.

Mayer, F. (1998), Interpreting NAFTA: The Science and Art of Political Analysis (New York: Columbia University Press).

McGregor, D. (2000), 'House Hands Clinton Policy Triumph on China', Financial Times, 25 May.

McParland, K. (1993), 'Clinton Pushes Sanctions in NAFTA Deals', The Financial Post, 15 May.

Merida, K. and K. Cooper (1993), 'Outsiders Looking in, Hill Republicans May be on the Verge of a Better View', The Washington Post, 25 September.

Milner, H. and P. Rosendorff (1997), 'Trade Negotiations, Information and Domestic Politics: The Role of Domestic Groups', Economics and Politics, 8, 2, 145-89.

Nacos, B., R. Shapiro and P. Isernia (2000), Decisionmaking in a Glass House: Mass Media, Public Opinion, and American and European Foreign Policy in the 21st Century (Lanham, MD: Rowman and Littlefield).

NBC News/Wall Street Journal (1992a), NBC News/Wall Street Journal Poll, September (Storrs, CT: The Roper Center for Public Opinion Research, University of Connecticut).

NBC News/Wall Street Journal (1992b), NBC News/Wall Street Journal Poll, October (Storrs, CT: The Roper Center for Public Opinion Research, University of Connecticut).

News Interest Index (1992), News Interest Index Poll, September (Storrs, CT: The Roper Center for Public Opinion Research, University of Connecticut).

Nollen, S. and D. Quinn (1994), 'Free Trade, Fair Trade, Strategic Trade, and Protectionism in the US Congress, 1987-1988', International Organization, 48, 3, 503-4.

Pew Research Center for the People (2001), Pew Research Center for the People Poll, August (Washington, DC: Pew Research Center).

Rhode, D. (1994), 'Partisanship, Leadership, and Congressional Assertiveness in Foreign and Defense Policy', in D. Deese (ed.), The New Politics of American Foreign Policy (New York: St. Martin's Press), 76-101.

Riddell, P. (1989), 'Bush Wins Reprieve on China', The Financial Times, 10 June.

Roper Organization. Roper Report 85-5, April 1985. Roper Center.

Sands, D. (1993), 'NAFTA Nations Cut Deal: Environment, Labor Items Pass', The Washington Times, 14 August.

Schattschneider, E. E. (1935), Politics, Pressures, and the Tariff: A Study of Free Enterprise in Pressure Politics (New York: Prentice Hall).

Sek, L. (2003), 'Trade Promotion Authority (Fast-Track Authority for Trade Agreements) Background and Developments in the 107th Congress', Congressional Research Service, 14 January.

Sherman, R. (2002), 'Delegation, Ratification, and US Trade Policy: Why Divided Government Causes Lower Tariffs', Comparative Political Studies, 35, 10, 1171-97.

Shoch, J. (2001), Trading Blows: Party Competition and US Trade Policy in a Globalizing Era (Chapel Hill, NC: UNC Press).

Skidmore, D. and W. Gates (1997), 'After Tiananmen: The Struggle Over US Policy Toward China in the Bush Administration', Presidential Studies Quarterly, 27, 3, 514-39.

Sparshott, J. (2005), 'House Votes to OK CAFTA', The Washington Times, 28 July.

Suettinger, R. (2003), Beyond Tiananmen: The Politics of US-China Relations, 1989-2000 (Washington: Brookings Institution Press).

Sutter, R. (1998), US Policy Toward China: An Introduction to the Role of Interest Groups (Lanham, MD: Rowman and Littlefield).

The Washington Post (2001) 'Thomas Upbeat on Trade Bill for Bush', 24 September.

Thorbecke, W. (1997), 'Explaining House Voting on the North American Free Trade Agreement', Public Choice, 92, 3/4, 231-42. 
Time/CNN/Yankelovich Partners (1993), Time/CNN/Yankelovich Partners Poll, May (Storrs, CT: The Roper Center for Public Opinion Research, University of Connecticut).

Tolchin, M. (1989), 'House, Breaking With Bush, Votes China Sanctions', The New York Times, 30 June.

Walker, M. (1989), 'US Stalls Nuclear Power Plant Deal', The Guardian, 13 June.

Weinraub, B. (1989), 'President Spurns Other Sanctions', The New York Times, 6 June.

Xie, T. (2008), US-China Relations: China Policy on Capitol Hill (New York: Routledge). 